\title{
PAWE BORKOWSKI
}

Uczelnia Łazarskiego w Warszawie

ORCID 0000-0001-8089-4101

pawel.borkowski@lazarski.pl

\section{Europejski Zielony Ład jako narzędzie modernizacjii legitymizacji projektu europejskiego}

\section{Modernizing and legitimating European integration project though New Green Deal}

Słowa kluczowe:

Nowy Zielony Ład, Unia Europejska, modernizacja, praworządność, gospodarka o obiegu zamkniętym, Pandemia Covid-19, Next Generation Europe
Keywords:

New Green Deal,

European Union, modernization, rule of law, circular economy, Covid-19 pandemic, Next Generation Europe 
Modernizing and legitimating European integration project though New Green Deal

CoviD-19 pandemic created a new environment to New Green Deal - flagship initiative of European Commission and crucial element of Ursula von der Leyen political manifesto. Author argues, that faced with the possibility of weakening or postponing ambitious environmental programme because of new challenges the commission, backed by important group pf member states decided to build a direct link between reconstruction after pandemics and greening of the economy. The result was a push forward with decarbonisation commitments - the stimuli for change should be bound together to strengthen their interdependence and build a momentum for modernization of EU in both economic and political dimensions. Conditionality of Next Generation Europe financial instrument is one of the links between these two dimensions. 


\section{Wprowadzenie}

owy Zielony Ład (European Green Deal) miał być jednym z flagowych projektów Komisji Europejskiej, której przewodniczy Ursula von der Leyen. Chodziło przy tym nie tylko o potwierdzenie globalnej roli promotora polityki przeciwdziałania wywołanym przez człowieka zmianom klimatycznym oraz modernizacyjny efekt gospodarczy, ale także, a może nawet przede wszystkim, o budowanie tożsamości UE jako aktora dostarczającego określone dobra i promującego określony zestaw wartości i styl życia. Zdaniem autora niniejszego opracowania obecność w jednej Komisji wiceprzewodniczących zajmujących się odpowiednio Zielonym Ładem, cyfryzacją i bezpieczeństwem informatycznym oraz europejskim stylem życia nie jest przypadkiem ani tym bardziej efektem nadmiaru komisarzy i wybujałej wyobraźni osób wymyślających nazwy stanowisk ${ }^{1}$. Wspomniane projekty łącza się, tworząc przemyślany program polityczny. Opracowanie będzie starało się to wykazać.

Pandemia CoviD-19, która dotarła do Europy na początku 2020 r., stworzyła zupełnie nowe warunki do realizacji wszystkich, mniejszych i szeroko zakrojonych, planów politycznych. Istniało zagrożenie, że wobec fundamentalnego przewartościowania i priorytetu nadanego sprawom zdrowia publicznego ambitne projekty, które mogły być uznane za swego rodzaju dobra luksusowe, mogą zostać ograniczone, poważnie okrojone lub odłożone ad calendas graecas. Instytucje UE odpowiedziały na to wyzwanie w inny sposób. Poniższe opracowanie będzie dowodzić, że KE i inne instytucje uznały rzeczywistość pandemiczną za szansę zdynamizowania procesów modernizacyjnych ${ }^{2}$. Decyzje podjęte w obliczu największego zagrożenia

1 Zobacz głosy krytyczne: The von der Leyen Commission: Lofty ambitions, odd job titles, Politico.eu [online], 10 IX 2019 [dostęp: 22 VIII 2021]: <https://www.politico.eu/ article/von-der-leyen-sets-priorities-with-new-commission-lineup/> oraz The E.U.'s ominous new name for a top migration job? Vice president for 'Protecting our European Way of Life," “The Washington Post" [online], 10 VIII 2019 [dostęp: 22 VIII 2021]: $<$ https://www.washingtonpost.com/world/2019/og/10/eus-ominous-new-name-top-migration-job-vice-president-protecting-our-european-way-life/ $>$. Nawet Przewodniczący PE David Sassoli określił proponowane nazwy jako „slightly original and bizarre".

2 P. Lamy, Greener After: A green recovery stimulus for Europe, Jacques Delors Institute, Paris 2020; S. L. Shaelou, Why the coronavirus crisis is still a moment of opportunity 
dla bezpieczeństwa państw europejskich od czasów wojny w b. Jugosławii, zwłaszcza ta o uwspólnotowieniu części długu państw strefy euro, stworzyły nowy kontekst dla planów Komisji, która postawiła na zorganizowaną „ucieczkę do przodu”. Efekty tej strategii nie są jeszcze znane, ale fakt jej konsekwentnego promowania, na tle niekiedy chaotycznych działań państw członkowskich, dowodzi, że powtarzana często w połowie 2020 r. opinia o nieprzygotowaniu/zbędności, nieużyteczności UE w warunkach pandemii była przedwczesna i nie potwierdziła się ${ }^{3}$. Kwestie energetyki, zielonej gospodarki, eliminacji śladu węglowego nie mogą być uważane za luksus bogatych, ale kluczowy element odbudowy świata popandemicznego nie tylko przywracającego mieszkańcom Europy mobilność i poziom życia, ale także szanującego planetę.

Opracowanie opiera się na dwóch koncepcjach teoretycznych, które tworzą ramę dla twierdzeń szczegółowych. Teoria pola Pierre'a Bourdieu wskazuje, że aktorzy polityczni w złożonym systemie nie tylko realizują zadeklarowane cele polityki (ad extra), ale także budują swoją tożsamość i pozycję w układzie władzy w systemie (ad intra). W tym kontekście

for the European Union, The Conversation [online], 12 VI 2020 [dostęp: 22 VIII 2021]: <https://theconversation.com/why-the-coronavirus-crisis-is-still-a-moment-of-opportunity-for-the-european-union-136877>; A. Bénassy-Quéré, B. Weder di Mauro, European pandemic recovery: An opportunity to reboot, "Intereconomics" 2020, vol. 55, no. 4, pp. 205-209, DOI: 10.1007/s10272-020-0903-3; M. Movarelli, EU democracy in the times of coronavirus, "European View" 2020, vol. 19, issue 2, s. 180-187, DOI: 10.1177/1781685820967770 (cały numer poświęcony jest Europie popandemicznej); E. Bajric, Could the "corona crisis" be a chance for a better future?, EyesOnEurope [online], 5 VIII 2020 [dostęp: 22 VIII 2021]: 〈https://www.eyes-on-europe.eu/could-the-corona-crisis-be-a-chance-for-a-better-future/ $\rangle$.

3 P.Zerka, In sickness and in health: European cooperation during the coronavirus crisis, ECFR Policy Brief [online], 8 VI 2020 [dostęp: 22 VIII 2021]: <https://ecfr.eu/ publication/in_sickness_and_in_health_european_cooperation_during_coronavirus_crisis/>; How Europe failed the coronavirus test, Politico.eu [online], 7 IV 2020 [dostęp: 22 VIII 2021]: 〈https://www.politico.eu/article/coronavirus-europe-failed-the-test/>; L. Elliott, The coronavirus crisis has brought the EU's failings into sharp relief, „The Guardian” News [online], 29 III 2020 [dostęp: 22 VIII 2021]: $<$ https://www.theguardian.com/business/2020/mar/29/the-coronavirus-crisis-has-brought-the-eus-failings-into-sharp-relief $>$; Profesjonalne zestawienie głosów wiosennej prasy, zob. Is the EU failing on crisis management?, Euro topics [online], 18 III 2020 [dostęp: 22 VIII 2021]: <https://www.eurotopics.net/en/237142/ is-the-eu-failing-on-crisis-management $\rangle$. 
działania Komisji i Parlamentu Europejskiego są traktowane jako podwójna odpowiedź na kryzys zdrowotny i tendencje promiędzyrządowe. Jak pisze Agnieszka Cianciara, „[s]ocjologiczny konstruktywizm [...] zwraca uwagę na fakt, że tworzenie określonej unijnej polityki nie musi wynikać (wyłącznie) z potrzeby rozwiązania realnego kolektywnego problemu". Kontynuując wywód, stwierdza: „Zgodnie z teorią pola P. Bourdieu decyzja polityczna nie jest zwykle rezultatem jasnego wyboru [...] ale efektem tego, co podczas interakcji dzieje się na wielu arenach, którzy to aktorzy, mający różny status (pozycje), starają się osiągać swoje cele indywidualne, instytucjonalne i polityczne [...] polityczny kompromis jest promowany (narzucany) przez dominujących aktorów, posiadających zasoby najbardziej cenione w danym polu"4. Podtrzymanie projektu Zielonego Ładu w warunkach pandemicznych było możliwe w tej perspektywie dzięki sojuszowi instytucji UE oraz kluczowych państw, w tym dysponujących największymi zasobami finansowymi i zaufaniem rynków Niemiec. Z kolei perspektywa instytucjonalizmu historycznego ze swoimi koncepcjami nieprzewidzianych konsekwencji i zależności od ścieżki dostarcza argumentów na rzecz powiązania momentu kryzysowego $\mathrm{z}$ długofalowym oddziaływaniem. Kompatybilne $\mathrm{z}$ tym pojęciem są koncepcje bricolage oraz "przedzierania się" (muddling through) stosowane w studiach europejskich m.in. przez Frédérica Méranda ${ }^{5}$, które wskazują na ograniczenia planowania decyzji politycznych, podejmowanych w gęstym środowisku aktorów różnie pojmujących i realizujących swoje interesy. Komisja występuje tutaj w roli agenda-setter oraz agenta wykorzystującego możliwość budowy własnej pozycji poprzez promowanie rozwiązań racjonalnych i przynoszących korzyści państwom mocodawcom. Wykorzystuje przewagę informacyjną, aby promować swoje priorytety jako wyraz europejskości, zwłaszcza jej najlepszej części. Tym samym Zielony Ład i agenda cyfrowa są propozycją uzyskania przez Unię, tudzież wzmocnienia, elementu tożsamości. Aktorzy ponadnarodowi odegrają rolę nie tylko facilitators, ale zrealizują swój program transformacji, który umocni ich pozycję poprzez konsekwentne dostarczanie wiedzy, rozwiązań i zasobów finansowych.

4 A Cianciara, Europejska Polityka Sąiedztwa w perspektywie konstruktywizmu, Instytut Studiów Politycznych PAN, Warszawa 2017, s. 75-76.

5 F. Mérand, Bricolage: A sociological approach to the making of CSDP, [w:] Explaining the EU's common security and defense policy, eds X. Kurowska, F. Breuger, Palgrave Macmillan, London 2012 (Palgrave Studies in European Union Politics). 
Jednocześnie należy podkreślić, że priorytety Komisji są zbieżne z interesami najsilniejszych państw członkowskich, a zwłaszcza ich przywódców i tych grup społeczeństwa, które postrzegają podważanie osiągnięć i sensowności procesów integracyjnych jako zagrożenie. Odzyskanie inicjatywy i legitymizacji przez Unię to dla nich szansa na powstrzymanie podważania ich pozycji przez ruchy o charakterze antysystemowym ${ }^{6}$. Zatem mamy do czynienia z synergią interesów instytucji ponadnarodowych i znacznej części państw członkowskich. Jest to sytuacja komfortowa dla Komisji, która ma przeciwko sobie tylko niektóre, zwykle peryferyjne, panstwa członkowskie oraz dążący do maksymalizacji założeń programu, ale skłonny do negocjacji, Parlament Europejski.

\section{Zielony Ład jako inicjatywa legitymizacji UE AD 2019}

Europejski Zielony ład był pierwszym punktem w dokumencie Unia, która sięga wyżej, politycznym manifeście Ursuli von der Leyen ${ }^{7}$. Komisja Europejska, która obejmowała z opóźnieniem urząd 1 listopada 2019 r., miała za zadanie nie tylko przyczynić się do efektywnego radzenia sobie z wyzwaniami stojącymi przed UE, ale także odnowić jej legitymację w oczach obywateli. W wyborach do PE w tymże roku eurosceptycy uzyskali ok. 20\% mandatów, choć wcześniejsze prognozy były dużo bardziej alarmistyczne ${ }^{8}$. Niemal apokaliptyczne przewidywania, że ich sukces sparaliżuje prace PE, nie sprawdziły się. Wydawało się, że jawiąca się wcześniej jako niepowstrzymana, fala prawicowego populizmu została zatrzymana i potrzebne było nowe otwarcie wykorzystujące nadchodzącą chwilę. Unia Europejska miała ukazać swoją przydatność, realizując ambitne plany transformacji rzeczywistości, w których kluczowe miejsce zajmował

6 E. Salvati, M. Vercesi, Anti-system Eurosceptic parties: Where and why they succeded, EUVisions [online], 4 IX 2017 [dostęp: 22 VIII 2021]: <http://www.euvisions. eu/archive/eurosceptic-parties-succeed/>; F. Hartleb, Here to stay: anti-establishment parties in Europe, "European View" 2015, vol. 14, no. 4, s. 39-49; L. Carrieri, The impact of European integration on West European politics, Palgrave Macmillan, London 2020, zwłaszcza rozdz 6.

7 Unia, która mierzy wyżej. Mój program dla Europy: wytyczne polityczne na następna kadencję Komisji Europejskiej (2019-2024), Unia Europejska 2019, DOI: 10.2775/612705.

8 P. Borkowski, Unia Europejska-próba przedolimpijska, „Rocznik Strategiczny” 2018/2019, s. 205-207. 
obywatel i jego potrzeby. Zatem chodziło o wykazanie związku między lepszymi warunkami życia a aktywnością UE. Odniesienie do ochrony środowiska, praw socjalnych i europejskiego stylu życia, podkreślane przez nową Komisję, służyły właśnie temu. Wytyczne były też jednoznacznie liberalne (nie neoliberalne!) - UE miała tworzyć warunki do samorealizacji świadomego obywatela świata. Warto przytoczyć jedno ważne zdanie ze wspomnianego dokumentu programowego. Przewodnicząca, mówiąc o perspektywie dla swoich dzieci, tak określiła Unię: „[Jest - P.B.] Praǵnieniem życia na kontynencie w naturalnych i zdrowych warunkach. Życia w społeczeństwie, w którym można być, kim się chce, mieszkać, gdzie się chce, kochać, kogo się chce, i mierzyć tak wysoko, jak się chce. To pragnnienie świata wypełnionego nowymi technologiami, ale opierającego się na odwiecznych wartościach. Europy, która przewodzi całemu światu w rozwiązywaniu głównych wyzwań naszych czasów" ${ }^{\prime 9}$. Perspektywa przyszłych pokoleń jest wyraźna, a program spójny, zaczynający się od kwestii ochrony środowiska, ale idący dalej, mocno w sferę wartości.

Należy zatem podkreślić, że Zielony Ład stał się projektem flagowym nie tylko jako naturalny kolejny etap agendy politycznej głównego promotora odpowiedzialności za stan planety ${ }^{10}$, ale także kluczowe z narzędzi odbudowania pozytywnego wizerunku UE. Działania proekologiczne cieszą się w Europie poparciem młodego pokolenia, co pokazuje popularność tzw. strajków klimatycznych ${ }^{11}$. Jednocześnie rośnie luka w poglądach między młodym pokoleniem a rządzącymi elitami. Popularność określenia "boomer" czy polskiego „dziadersi" ${ }^{12}$ dowodzi istotnej różnicy w priorytetach między grupą obecnie rządzącą a młodymi wyborcami. Przejęcie ich priorytetów to jedyna potencjalnie skuteczna droga odbudowy legitymizacji. Warto spojrzeć na program nowej Komisji, jego z całą pewnością

9 Unia, która mierzy..., s. 3.

10 Unia określa tak siebie w programowym dokumencie Europejski Zielony Ład, Komunikat Komisji do Parlamentu Europejskiego, Rady Europejskiej, Rady, Komitetu Ekonomiczno-Społecznego i Komitetu Regionów, $\operatorname{COM}(2019) 640$ final, Komisja Europejska, Bruksela 2019, s. 2: 〈https://eur-lex.europa.eu/resource. html?uri=cellar:b828d165-1c22-11ea-8c1f-01aa75ed71a1.0016.02/DOC_1\&format=PDF $>$ [dostęp: 22 II 2021].

11 Ursula von der Leyen nawiązuje do nich bezpośrednio w swoim manifeście.

12 Fraza „Ok, boomer" daje w wyszukiwarce Google ponad 36 mln wyników, określenie „dziadersi" - ok. 57 tys. 
odświeżony język jako wyraz wysiłku na rzecz budowy porozumienia z tymi uczestnikami życia publicznego, dla których zero waste, brak kontroli granicznych, swoboda poszukiwania swojego miejsca w świecie są naturalne, zatem oczekują ochrony i umacniania tych elementów konstrukcji europejskiej, które je zapewniają.

Przedłużający się proces wyłaniania i zatwierdzania Komisji Europejskiej $^{13}$ dał czas na przygotowanie planów, które mogły uzyskać poparcie „obozu prointegracyjnego” w PE. Współpraca kiedyś rywalizujących mainstreamowych partii pozwala im zachować decydujący wpływ na legislację i prezentować się jako obóz racjonalnej i nowoczesnej odpowiedzi na wyzwania XXI w. Tym samym nie należy do przedstawionego przez Komisję 11 grudnia 2019 r. dokumentu przykładać tradycyjnych kryteriów poszukiwania elementów lewicowych i prawicowych, neoliberalnych czy etatystycznych. Nowa Komisja dostała przyzwolenie na ambitną agendę jako instrument przynajmniej częściowej odbudowy poparcia dla UE, uczynienia jej atrakcyjnym produktem dla świadomych młodych wyborców.

Okoliczności sprawiły, że wspomniany Komunikat przedstawiono miesiąc przed wykryciem przypadków choroby coviD-19 w Europie i realizacja jego założeń natychmiast potrzebowała rewizji. Nie obniża to znaczenia dokumentu, którego zawartość pozwala wyciągnąć kilka istotnych wniosków co do stanu przygotowań i horyzontu wyobrażeń o Zielonej Europie na przełomie 2019 i 2020 r. Najważniejsze zdaniem autora są trzy punkty:

- Mocne powiązanie ze sobą Zielonego Ładu, gospodarki o obiegu zamkniętym, cyfryzacji i nowej polityki przemysłowej.

- Mały stopień konkretności zapowiedzi zmian w zakresie Wspólnej Polityki Rolnej (WPR) oraz praw społecznych, które mają być niezbędnym elementem strategii, ale nie wskazano realnie, w jaki sposób. Co więcej, podkreślanie roli europejskiego rolnictwa i jakości jego produktów sugeruje dużą ostrożność w ewentualnym antagonizowaniu beneficjentów WPR.

- Podkreślenie znaczenia sektora prywatnego przy pozostawieniu otwartej kwestii, w jaki sposób skłaniać np. rynki finansowe do uwzględniania „zielonych" priorytetów.

13 New EU Commission delayed for at least a month, EUractiv [online], 17 X 2019 [dostęp: 22 VIII 2021]: <https://www.euractiv.com/section/eu-elections-2019/news/ new-eu-commission-delayed-for-at-least-a-month/ $>$. 
W relacjach medialnych na czoło wysunęła się zapowiedź uzyskania neutralności emisyjnej przez cały blok najpóźniej do 2050 r. $^{14}$. Oczywiście wymaga to szczególnie głębokiej transformacji sektora produkcji energii, ale zagadnienie ma charakter horyzontalny i w swej istocie dotyka nie tylko stylu produkcji, lecz właśnie „stylu życia”. Tym samym świadomość odpowiedzialności wobec przyszłych pokoleń i szeroka promocja oszczędzania zasobów są co najmniej równie ważne, jak rezygnnacja $\mathrm{z}$ węgla. W tym konkretnie wypadku świadomość musi kształtować byt, a nie odwrotnie. Kształtowanie narracji i promowanie postaw proekologicznych to jedno z zasadniczych narzędzi uczynienia transformacji energetycznej zadaniem całego społeczeństwa.

UE została określona w komunikacie jako światowy lider w dziedzinie działań na rzecz klimatu i środowiska, a także ochrony konsumentów i praw pracowniczych. Te dwa dalsze elementy wyrażają europejski model socjalny i są częścią składową wspomnianego „stylu życia”. Pozostaje problem podtrzymania go $\mathrm{w}$ warunkach rosnącej globalnej konkurencji. Tym samym proliferacja norm promowanych przez UE w skali międzynarodowej nie jest dodatkiem, ale uświadomioną koniecznością. Zapobieganie „ucieczce emisji” to tylko jeden z aspektów budowania świata zrównoważonego rozwoju ${ }^{15}$. Bez konkurencyjności i wzrostu poziomu życia odczuwanego przez szerokie grupy społeczne skłonienie obywateli do płacenia więcej za produkty powstające z poszanowaniem planety będzie nie tylko trudne,

14 Dwa kluczowe zdania dokumentu: „Jest to nowa strategia na rzecz wzrostu, której celem jest przekształcenie UE w sprawiedliwe i prosperujące społeczeństwo żyjące w nowoczesnej, zasobooszczędnej i konkurencyjnej gospodarce, która w 2050 r. osiągnie zerowy poziom emisji gazów cieplarnianych netto i w ramach której wzrost gospodarczy będzie oddzielony od wykorzystania zasobów naturalnych”, oraz „Komisja przygotuje ocenę skutków i przedstawi plan zwiększenia, w odpowiedzialny sposób, do co najmniej $50 \%$, a potencjalnie do $55 \% \mathrm{w}$ stosunku do poziomu w 1990 r., unijnego celu na 2030 r. zredukowania emisji gazów cieplarnianych. Aby osiągnąć tę dodatkową redukcję emisji gazów cieplarnianych, Komisja przeprowadzi do czerwca 2021 r. przegląd wszystkich znaczących instrumentów polityki związanych z klimatem i, w razie potrzeby, zaproponuje ich zmiany". Zob. też Polska w Zielonym Ładzie - korzyści, możliwości i ocena SWOT, Kancelaria Senatu RP, Warszawa 2020 (Opinie i Ekspertyzy OE, 307).

15 The geopolitics of the European Green Deal, ECFR Policy Brief [online], 3 III 2021 [dostęp: 22 VIII 2021]: 〈https://ecfr.eu/publication/the-geopolitics-of-the-europeangreen-deal/>. 
ale zostanie uznane za hipokryzję. Aspekt socjalny projektu modernizacyjnego UE jest zresztą dyskutowany. Preferencja rynku w duchu neoliberalizmu poddawana jest mocnej krytyce od czasu kryzysu finansowego $2008 \mathrm{r}$., jednak wciąż ma zwolenników, upatrujących w logice konkurencyjności jedyną drogę do zachowania pozycji UE. Zasadniczo jednak gros głosów wskazuje, że europejski styl życia, używany jako ważny element legitymizowania UE, opiera się m.in. na budowie państwa dobrobytu w nowoczesnym ujęciu. Nie sposób go zachować/umocnić bez wysokiego poziomu usług publicznych. Ciekawą polemikę $\mathrm{w}$ tej sprawie prowadzili wiosną 2021 r. na łamach portalu Onet Opinie Michał ks. Liechtenstein i Jan Zygmuntowski ${ }^{16}$. Na gruncie kultury popularnej przejawem tego „europejskiego stylu" jest cała grupa memów wskazująca na bezpłatną służbę zdrowia jako wyraźną przewagę względem tego, co amerykańskie. Zachowanie zdobyczy socjalnych jest sprawą kontrowersyjną zarówno w samej UE, jak i w poszczególnych państwach członkowskich. Dyskusje wokół dyrektywy o pracownikach delegowanych to tylko wierzchołek sporu, w którym padają takie określenia jak dumping socjalny i nieuczciwa konkurencja ${ }^{17}$. Problem wymaga dalszych intensywnych badań - autor nie czuje się w nich specjalistą - ale także decyzji politycznej o konsekwentnym zaliczeniu (bądź nie) zdobyczy welfare state do europejskiego stylu życia.

Drugim projektem priorytetowym Komisji Europejskiej była agenda cyfrowa. Łączą się $\mathrm{w}$ niej aspekty bezpieczeństwa, zmiany postrzegania pracy oraz dostępu do komunikacji elektronicznej i informacji jako ważnego prawa podstawowego. Postrzeganie dostępu do Internetu jako prawa człowieka, które umożliwia korzystanie z innych dostępnych dóbr

16 Bez państwa dobrobytu i strategiii rozwoju Europa nie będzie dobrym miejscem do życia, Onet Wiadomości [online], 14 III 2021 [dostęp: 22 VIII 2021]: <https://wiadomosci.onet. pl/opinie/bez-panstwa-dobrobytu-i-strategii-rozwoju-europa-nie-bedzie-dobrym-miejscem-do-zycia/m39pcyw> oraz Europa i USA nie wygraja wyścigu o przywództwo $z$ Chinami zwiększając zaangażowanie państwa w gospodarkę, Onet Wiadomości [online], 12 III 2021 [dostęp: 22 VIII 2021]: 〈https://wiadomosci.onet.pl/opinie/europa-i-usa-nie-wygraja-wyscigu-o-przywodztwo-z-chinami-zwiekszajac-zaangazowanie/ p77p881>.

17 B. Surdykowska, D. Owczarek, Posted workers regulations as a cohesion test in the enlarged European Union: divergent interests of trade unions, employers' organisations and governments, Friedrich-Ebert-Stiftung, Bratislavia 2018. 
i realizowanie wartości, jest elementem nowoczesnego postrzegania cyfryzacji i jej wyzwań. Komisja opublikowania dokument programowy w tym zakresie 19 lutego 2020 r. Zatytułowany Europejska agenda cyfrowa ${ }^{18}$ i mający charakter horyzontalny komunikat Komisji definiuje główne cele jako:

- przeprowadzenie transformacji cyfrowej w taki sposób, aby przyniosła ona korzyść wszystkim (obywatelom, przedsiębiorcom i środowisku) i pozwoliła na zbudowanie społeczeństwa opartego na rozwiązaniach cyfrowych, z poszanowaniem europejskich wartości;

- suwerenność technologiczna, którą KE rozumie jako integralną i odporną infrastrukturę, sieć i komunikację;

- wykształcenie własnych zasad i wartości w epoce cyfrowej;

- budowa zaufania obywateli i biznesu do technologii i produktów cyfrowych.

Warto podkreślić, że cyfryzacja to jedno z narzędzi zapewnienia efektywniejszego wykorzystania zasobów i zmniejszania np. tzw. śladu węglowego jednostek i produktów. Dokument był już wielokrotnie poddany analizom, a został wyodrębniony w opracowaniu jako strategia, podobnie jak Zielony Ład, horyzontalna i modernizacyjna. Ich sukces wydaje się przynajmniej w znacznym stopniu współzależny ${ }^{19}$. Praca smart i z użyciem możliwości oferowanych przez świat cyfrowy przyczyni się do sukcesu transformacji energetycznej, ta z kolei zwiększy atrakcyjność rozwiązań opartych na digitalizacji i aktywności online.

18 Europejska agenda cyfrowa, Komunikat Komisji do Parlamentu Europejskiego, Rady, Europejskiego Komitetu Ekonomiczno-Społecznego i Komitetu Regionów, $\mathrm{COM} / 2010 / 0245$ final.

19 Autorowi przypadło do gustu zwłaszcza jedno z jego pierwszych zdań: „Kryzys zniweczył wyniki wielu lat postępu gospodarczego i społecznego oraz odsłonił strukturalne słabości europejskiej gospodarki. Głównym celem Europy musi być teraz powrót na drogę wzrostu gospodarczego. Jednak aby zbudować zrównoważoną przyszłość, musimy już teraz wyjść poza horyzont celów krótkoterminowych. W obliczu starzenia się społeczeństwa i globalnej konkurencji mamy do wyboru trzy opcje: pracować ciężej, dłużej lub mądrzej. Będziemy prawdopodobnie musieli zastosować wszystkie trzy, ale trzecia opcja to jedyny sposób na zagwarantowanie lepszej jakości życia Europejczyków". 
Pandemia - niespodziewane i nieprzewidywalne uwarunkowanie Zielonego Ładu

Pandemia covid-19 przydarzyła się w momencie dyskusji nad programem Komisji i sposobami jego wdrożenia, w którą zaangażowane były zarówno państwa członkowskie, jak i Parlament Europejski. Perspektywa porzucenia projektu Zielonego Ładu, jawiącego się jako stanowczo mniej pilny niż zagrożenie zdrowotne, była realna i być może kusząca. Wiosną 2020 r. pojawiły się wypowiedzi polityków, zwykle z państw i tak niechętnych zbyt ambitnym planom ekologicznym. Głos zabrał m.in. minister klimatu RP Michał Kurtyka oraz wiceminister aktywów państwowych Janusz Kowalski ${ }^{20}$. Najmocniej i na najwyższym szczeblu wypowiedział się na ten temat premier Czech Andrej Babiš, stwierdzając 16 marca, że UE powinna zapomnieć o Zielonym Ładzie i skupić wysiłki i środki na walce $\mathrm{z}$ wirusem $^{21}$. Już w marcu 2020 r. było to jasne . Pojawiły się też głosy wewnątrz państw członkowskich - macierzysta Partia Narodowo-Liberalna wystosowała do eurodeputowanych rumuńskich wezwanie do podjęcie na forum PE działań, aby odrzucić lub zamrozić projekt ${ }^{22}$.

Również urzędnicy UE odnotowali - nomen omen - zmianę atmosfery. Informator Politico wypowiadał się następująco: „Każdy zadawał jedno pytanie - czy to zdusi incjatywę? Przez kilka pierwszych tygodni dominowała panika, gdy wszyscy zastanawiali się, jak sprawić, by przeżyli ludzie

20 Zwłaszcza wypowiedź tego ostatniego jest symptomatyczna: „należy zapomnieć o absolutnie ideologicznych planach Fransa Timmermansa podkręcania celów klimatycznych do 2030 roku. Europa zacznie zapominać o zielonym ładzie rozumianym jako wielki regulacyjny i ideologiczny pomysł europejski na politykę klimatyczną mającą obciążać gospodarki. Koronawirus wyeliminuje ten sposób myślenia, bo nie będzie na to pieniędzy"; pełny tekst wywiadu: Kowalski: Koronawirus każe wyłączyć Polskę z ETS i zapomnieć o Europejskim Zielonym Ładzie, Biznes Alert [online], 18 III 2020 [dostęp: 22 VIII 2021]: 〈https://biznesalert.pl/ kowalski-wylaczyc-polske-z-ets-europejski-zielony-lad-energetyka-klimat/ $\rangle$.

21 Czech PM urges EU to ditch Green Deal amid virus, Euractiv [online], 17 III 2020 [dostęp: 22 VIII 2021]: <https://www.euractiv.com/section/energy-environment/ news/czech-pm-urges-eu-to-ditch-green-deal-amid-virus/ $>$.

22 M. Elkerbout, C. Egenhofer, J. N. Ferrer, M. Cătuţi, I. Kustova, V. Rizos, European Green Deal after corona: Implications for EU climate policy, CEPS Policy Insight [online], 31 III 2020, s. 2: <https:/www.ceps.eu/wp-content/uploads/2020/03/ PI2020-06_European-Green-Deal-after-Corona.pdf > [dostęp: 22 VIII 2021]. 
i gospodarka. To, co zielone, po prostu spadło z agendy"23. Jednak sytuacja rozwinęła się w zupełnie innym kierunku. Dobrym wprowadzeniem do rozpoznania powodów tegoż będzie cytat z przemówienia kanclerz Angeli Merkel:

„Pandemia pokazała, jak kruchy pozostaje projekt europejski. Pierwsze reakcje, $\mathrm{w}$ tym nasze własne, były raczej narodowe i nieszczególnie europejskie. To, nieważne jak słuszne mogły być motywy, było przede wszystkim nierozsądne. Ponieważ globalna pandemia potrzebuje wspólnych działań międzynarodowych i wzajemnego wsparcia. Pandemia podkreśliła także zależność Europy od państw trzecich w zakresie produkcji leków i środków ochronnych. Ich pozyskanie, przechowanie i rozdział ujawniły braki. Różnice w sytuacji gospodarczej i budżetowej państw członkowskich także zostały wyostrzone przez pandemię. Pokazuje ona nam, że Europa jest podatna [na wstrząsy]. To dlatego mówię z pełnym przekonaniem: nigdy wcześniej spójność i solidarność nie były w Europie tak ważne, jak są dzisiaj"24.

Najważniejsze państwa porozumiały się w kwestii odbudowy uwzględniającej cele Zielonego Ładu. We wspólnym oświadczeniu przywódców Francji i Niemiec z 28 czerwca 2020 r. po spotkaniu w Meserbergu ${ }^{25}$ zaproponowano - wobec wcześniejszych głosów, że należy np. ograniczyć „zielenienie" gospodarki - połączenie walki z pandemią i odbudowy gospodarczej z nowym zielonym ładem i agendą cyfrową. Prezydent Francji i kanclerz Niemiec optowali za tym, aby użyć szczególnych warunków jako swoistej szansy na postęp $\mathrm{w}$ dwóch ważnych sferach. $\mathrm{O}$ ile wobec przejścia w bardzo wielu miejscach na pracę zdalną podkreślenie związku z cyfryzacją i nowymi technologiami wydaje się dość oczywiste, o tyle kwestie polityki klimatycznej i energetycznej mogły paść ofiarą sytuacji zagrożenia zdrowia publicznego. Ustalono jednak, że odbudowa i stymulowanie gospodarki

23 How the EU's Green Deal survived the coronavirus pandemic, Politico.eu [online], 17 XII 2020 [dostęp: 22 VIII 2021]: <https://www.politico.eu/article/ how-eu-climate-change-promises-survived-the-coronavirus-plague/ $\rangle$.

24 Pełny tekst przemówienia dostępny: Regiierungsserklärung von Bundeskanzlerin Merkel in Berlin vor dem Deutschen Bundestag (Protokoll des Deutschen Bundestages), Bundeskanzler [online], 18 VII 2020 [dostęp: 22 VIII 2021]: <https:/www.bundeskanzlerin.de/ bkin-de/aktuelles/regierungserklaerung-von-bundeskanzlerin-merkel-1762594〉.

25 Merkel and Macron show unity ahead of all-important EU summit, EUraktiv [online], 30 VI 2020 [dostęp: 22 VIII 2021]: 〈https://www.euractiv.com/section/future-eu/ news/merkel-and-macron-show-unity-ahead-of-all-important-eu-summit/ $>$. 
będzie połączone z jej przestawianiem na „zielone” tory ${ }^{26}$. Warto podkreślić, że jest to klasyczne wykorzystanie kryzysu jako impulsu „ucieczki do przodu" wobec przeszkody na tyle poważnej, że bussines as usual był całkowicie niemożliwy ${ }^{27}$. Jak ujęła to szefowa Europejskiej Fundacji na rzecz Klimatu (European Climate Foundation - ECF) Laurence Tubiana: „Mieliśmy wtedy wybór - porzucić program lub go wzmocnić" ${ }^{28}$.

Doszło do stworzenia nieformalnego, ale $\mathrm{w}$ swej istocie wspólnego frontu złożonego z przewodniczącej Komisji, skupionej na realizacji obietnic z 2019 r., przewodniczącego Rady Europejskiej Charles'a Michela, zainteresowanego sukcesem negocjacji na szczycie oraz wpływowych posłów z różnych frakcji, które można określić jako proeuropejskie. Parlament będzie nadal krytyczny wobec propozycji, które nazwie nieraz „rozwodnionymi”, ale opowie się jednoznacznie za uczynieniem z Zielonego Ładu fundamentu programu odbudowy. Analitycy Politico wskazują, że najważniejsza w tej „układance" była decyzja Angeli Merkel, która nie ugięła się pod presją silnego w Niemczech lobby producentów samochodów. Byli oni od dawna zapleczem politycznym dla partii chadeckiej, jednak gdy w czerwcu 2020 r. kanclerz przedstawiała niemiecki narodowy pakiet odbudowy, warty $130 \mathrm{mld}$ euro, okazało się, że nie ma w nim dotacji na zakup samochodów innych niż elektryczne. Jak podsumowuje Politico, „przekaz był jasny: unowocześnijcie się lub gińcie"29. Tym samym wobec presji na zazielenienie gospodarki ugiąć musiały się nawet sektory traktowane jako „srebra rodowe”, cieszące się dotąd szczególnymi względami. Pod auspicjami Parlamentu Europejskiego powołano Green Recovery Alliance, składający się z deputowanych, prezesów firm, stowarzyszeń pracodawców i związków zawodowych oraz NGO-sów ${ }^{30}$. Mieliśmy zatem do czynienia z utworzeniem zróżnicowanego lobby, które stawiało sobie za cel zapobiec odsunięciu kwestii ekologicznych na dalszy plan, a właśnie uczynienie z nich kluczowego elementu programu odbudowy.

26 Macron, Merkel call for swift agreement on EU Covid-19 recovery fund, rfi [online], $29 \mathrm{VI}$ 2020 [dostęp: 22 VIII 2021]: <https://www.rfi.fr/en/europe/20200629-macron-and-merkel-meet-ahead-of-decisive-german-presidency-of-eu $>$.

27 F. Colli, The end of "bussines as usual"? CoviD-19 and the European Green Deal, Egmont Institute, Brussels 2020 (Policy Brief No 60).

28 How the EU's Green Deal...

29 Tamże.

30 F. Colli, The end of "bussines as usual"?, s, 4. 
Ostatecznie 9 kwietnia 2020 r. opublikowano list sygnowany przez ministrów 10 rządów, wzywający formalnie wszystkie państwa do skupienia się wokół powyższej idei ${ }^{31}$. W ciągu kilku dni ta liczba wzrosła do $17^{32}$, co oznaczało, że udało się zbudować szeroką, większościową koalicję, która zdecydowana była poprzeć propozycje Komisji.

Dobrym podsumowaniem jest porównanie z kryzysem finansowym i ówczesnym klimatem niesprzyjającym promowaniu zachowań i działań proekologicznych. Jak anonimowo wypowiedział się urzędnik Komisji, "[d]ziś jest zupełnie inaczej niż 10 lat temu. Nie dlatego, że jesteśmy lepszymi politykami, ale dlatego, że świat się całkowicie zmienił"33. Zmiana ta polega nie tylko na spadku cen energii produkowanej ze źródeł odnawialnych oraz wzroście świadomości, zwłaszcza młodego pokolenia. Doszło również do swoistego policzenia się zwolenników progresywnej, proekologicznej zmiany, a to wszystko razem uczyniło Zielony Ład centralnym elementem modernizacji i relegitymizacji projektu integracyjnego ${ }^{34}$.

Zielony Ład to nie tylko sfera produkcji i konsumpcji energii. Komisja rozszerza wizję owego ładu na nowe sfery, m.in. politykę przemysłową czy produkcję chemikaliów. Opublikowała m.in. strategię dotycząca gospodarki środkami chemicznymi ${ }^{35}$ oraz dokonała rewizji polityki przemysłowej. Uznano, że

31 Pełna treść listu już 17 sygnatariuszy: European Green Deal must be central to a resilient recovery after Covid-19, Climate Home News [online], 9 IV 2020 [dostęp: 22 VIII 2021]: <https://www.climatechangenews.com/2020/o4/o9/european-green-deal-mustcentral-resilient-recovery-covid-19/ $>$.

32 Sygnatariusze: Austria, Dania, Finlandia, Włochy, Łotwa, Luksemburg, Niderlandy, Portugalia, Hiszpania, Szwecja; dołączyły się: Francja, Słowenia, Słowacja, Malta, Niemcy, Grecja, Irlandia; A. Doyle, Four more EU nations back a green post-coronavirus recovery, Climate Home News [online], 20 IV 2020 [dostęp: 22 VIII 2021]: $<$ https://www.climatechangenews.com/2020/04/20/four-eu-nations-back-greenpost-coronavirus-recovery/ $>$.

33 How the EU's Green Deal...

34 Zobacz krótkie, ale znakomicie podkreślające kluczowe punkty opracowanie: P. Hofhuis, The European Commission on the brink of a green recovery. Will it be able to deliver?, Netherlands Institute of International Relations, Clingendale 2020 (Policy Brief).

35 Chemicals strategy for sustainability. Towards a toxic-free environment, Communication from the Commission to the European Parliament, the Council, the European Economic and Social Committee and the Committee of the Regions, COM (2020) 667 final, $14 \times 2020$. 
wprowadzanie $\mathrm{w}$ życie Zielonego Ładu to dobry czas na intensywne promowanie modernizacji przemysłu i modeli prowadzenia biznesu. „Zielenienie” gospodarki ma się stać unijną strategią wzrostu. Z kolei cyfryzacja powinna być przyśpieszona, wykorzystując szczególną sytuację pandemiczną. Nie powinno się przy tym zapominać o cyfrowej niezależności ${ }^{36}$.

Konsekwencją pandemii była zgoda Niemiec na uwspólnotowienie europejskiego długu (niewielkiej części, ale kluczowe jest wycofanie sprzeciwu) oraz umocnienie przekonania o niezbędności rozwoju unijnej polityki przemysłowej ${ }^{37}$. Przyjęcie potężnego pakietu na rzecz odbudowy i wzrostu Next Generation Europe było połączone z wprowadzeniem zasady warunkowości względem przestrzegania zasad UE, w tym poszanowania praworządności. Należy to rozpatrywać całościowo - bardzo mocno dyskutowana zasada, która doprowadziła do groźby weta Polski i Węgier wobec ustaleń Rady Europejskiej, nie została wprowadzona w próżni. Modernizacja, która ma ponownie ożywić i legitymizować projekt europejski, ma różne wymiary i dotyczy także modelu społeczeństwa. Państwa Europy Zachodniej zdają sobie sprawę, że naruszenia niezawisłości władzy sądowniczej w Polsce i na Węgrzech nie są po prostu elementem zmiany równowagi ustrojowej, ale procesem usuwania przeszkód dla ręcznego zapobiegania europeizacji w sferze kultury i obyczaju. Przekonanie, że nie da się „wyciąć" i osłonić jednej ze sfer życia społecznego od procesów modernizacyjnych, jest prawdziwe - dotąd raczej podnoszono ten argument. wskazując na ograniczenia efektywności gospodarki Chin przy zachowaniu modelu władzy monopartii o charakterze oligarchiczno-korporacyjnym. Jednak może być on zastosowany także do prób zatrzymania europeizacji w państwach Europy Środkowej.

36 Autor ma pewne opory przed używaniem pojęcia digital sovereignty, które może oznaczać zarówno suwerenność w sferze cyfrowej, jak i suwerenność cyfrową, które to pojęcia nie są ani jednoznaczne, ani tożsame.

37 Rok 2020 pokazał, jak o wiele bardziej złożona i wymagająca jest kwestia suwerenności we współczesnym świecie. Redukowanie jej do możliwości podejmowania samodzielnych decyzji w sferze ustroju sądownictwa czy kontroli nad mediami prowadzi do faktycznej uraty możliwości mierzenia się z globalnymi tendencjami i zagrożeniami. Potencjał naukowy umożliwiający niezależność np. w kwestii szczepionek oraz możliwość efektywnego przeciwdziałania akcjom dezinformacyjnym, mającym zachwiać morale i spójność społeczną, zdobyły należną im rangę w świadomości, czym jest strategiczna suwerenność. 
Kluczowe elementy planowanej transformacji dobrze podsumowali badacze Fundacji na rzecz Europejskich Studiów Progresywnych, związanej z frakcją socjaldemokratyczną w Parlamencie Europejskim: „Zielony Ład przedstawia nową wizję, która dąży do wzmocnienia jedności UE poprzez jednoczesne formułowanie odpowiedzi na wyzwania ekologiczne, ekonomiczne i społeczne tak, aby wzmacniały się one wzajemnie. Dostrzega potrzebę głębokiej transformacji natury wzrostu gospodarczego. Wobec ukazania kruchości istniejącego system gospodarczego Zielony Ład dostarcza najlepszą istniejącą ramę dla wejścia na drogę odbudowy połączonej z ulepszeniami tak, aby wzmocnić odporność na przyszłe szoki [dla gospodarki - P.B.]"38. Jeszcze mocniej zaznaczyli to badacze szwedzcy, odnosząc się do kwestii budowania gospodarki o obiegu zamkniętym: „Ocena Siódmego Planu Działań na rzecz Środowiska sformułowana przez Komisję w 2019 r. wskazała, że w krajach rozwiniętych uzyskanie zrównoważonej gospodarki zasobami będzie wymagało redukcji konsumpcji" ${ }^{\prime 3}$. [...] Model biznesowy wciąż jest w większości oparty na zasadzie więcej ludzi kupuje więcej produktów - jest on już niekompatybilny $\mathrm{z}$ bezpieczną i zrównoważoną przyszłością" ${ }^{n 0}$. Jest to bardzo wyraźna zmiana i dowód na ostateczne odejście od neoliberalnego przekonania, że wzrost mierzony wskaźnikiem GDP lub średnim poziomem konsumpcji jest kluczowym elementem każdego racjonalnego programu politycznego. Wokół tego przekonania zjednoczyły się Komisja, Parlament, organizacje pozarządowe oraz państwa członkowskie reprezentujące europejski mainstream. Kryzys zdrowotny i kolejny gospodarczy pokazał, jak potrzebna może być dobrze działająca Unia. Działania ponadnarodowe są odpowiedzią na rosnącą podatność na wstrząsy, tylko ich efektywność może przekonać obywateli, że warto pokładać nadzieję w „Europie" ${ }^{\text {"41 }}$.

Decyzja o kontynuowaniu planu zazielenienia europejskiej gospodarki $\mathrm{w}$ powiązaniu z popandemiczną odbudową miała dwa istotne aspekty.

38 Green Deal for all. Sustainability and equity between people, regions, countries and generations, Policy report, Foundation for European Progressive Studies, Brussels 2020.

39 Delivering a circular economy within the planet's boundaries. An analysis of the new EU Circular Economy Action Plan, Stockholm Environment Institute 2020, s. 6.

40 Tamże, s. 24.

41 Są też głosy o zasadniczej nieskuteczności planu zawartego w dokumentach Komisji i wzniosłych decyzjach przywódców UE, zob. np. S. Storm, The EU's Green Deal: Bismarck's 'what is possible' versus Thunberg's 'what is imperative', Institute for New Economic Thinking, March 2020, s. 11 (Working Paper No 117). 
Jak zauważono: „Kryzys dostarczył także niekoniecznie chcianego eksperymentu - kurczenie się jako strategia zazieleniania gospodarki. Emisje zapewne znacząco spadną, ale znacząco więcej ton $\mathrm{CO} 2$ będzie wyemitowanych mimo redukcji końcowego produktu aktywności gospodarczej. Transformacja w stronę neutralności klimatycznej potrzebuje redukcji tylko aktywności określanej jako carbon-intensive i szybkiego wzrostu w pozostałych sektorach" ${ }^{42}$. Uwidoczniła się również użyteczność UE, i to w sferze bezpośrednio interesującej obywateli. Jak zauważyli szwedzcy eksperci: „radzenie sobie ze zmianą klimatu wymaga takiego rodzaju międzyregionalnej i wielonarodowej koordynacji, jakiej dostarcza Bruksela. Unia doskonale sobie radzi w szczegółowych regulacjach dotyczących technicznego charakteru produktów. Ma do dyspozycji komitety, które mogą uzgodnić "normative frameworks for a taxonomy for classifying environmentally sustainable activities". Unia Europejska jest także szczególnie dobrze przygotowana i ma znaczne doświadczenie w redystrybucji zasobów między regionami, co oznacza, że jest w stanie wspomóc obszary, których tkanka zależy od aktywności opartej na spalaniu węgla"43. Powiązanie aktywności UE jest zatem szczególnie widoczne $\mathrm{w}$ sferze zapewnienia sprawiedliwej transformacji i wsparcia dla szczególnie „wymagających pracy” regionów.

Nie wiemy jeszcze, czy plany popandemicznej zielonej odbudowy (green recovery) zostaną zrealizowane - nie zbadano dotąd poziomu „oporu materii" wobec wysiłku transformacyjnego. Można natomiast wskazać, jakie elementy wydają się niezbędne, aby przynajmniej umożliwić sukces. Institute for European Environmental Policy opublikował w lipcu 2020 r. przegląd propozycji „zielonych" think-tanków w tym zakresie. Otrzymany obraz identyfikuje cztery kluczowe elementy. Są to: polityka fiskalna formułowana w długim horyzoncie czasowym, powszechne uznanie wartości (ekonomicznej) środowiska i jego usług na rzecz populacji, odporny na wstrząsy powszechny system opieki zdrowotnej oraz skupienie środków finansowych na sferze badań i innowacji ${ }^{44}$. Jest to program z gruntu modernizacyjny i jednocześnie nieneoliberalny. Unia stać się ma zatem czempionem inno-

42

43

44

Delivering a circular, s. 9.

Tamże, s. 4 .

What constitutes European green recovery?, Institute for European Environmental Policy [online], 28 VII 2020 [dostęp: 22 VIII 2021]: <https://ieep.eu/publications/ what-constitutes-a-european-green-recovery>. 
wacji nie w imię produktywności, ale uczynienia życia Europejczyków lepszym. Na tym może polegać „european way of life”, choć powodzenie projektu nie jest przesądzone.

\section{„Tak zostało napisane i niech tak się stanie”}

2020 był dziwnym rokiem. Dla UE zaowocował dwiema istotnymi zmianami. Pierwsza z nich to decyzja o emisji uwspólnotowionego długu strefy euro. To zmiana stanowiska Niemiec, do tej pory jednoznacznie sprzeciwiających się temu krokowi, otworzyła drogę do dużego programu odbudowy, opartego m.in. na emisji papierów dłużnych. Druga zmiana to powiązanie wykorzystania środków finansowych z przestrzeganiem zasady praworządności. Słuszne są uwagi badaczy, że jej kontrola została osłabiona, a ostatecznie oczekiwać należy orzeczenia TSUE, jednak decyzja ta i tak może być uznana za przełomową. Sam fakt możliwości odebrania finansowania i lepszej ochrony przed sprzeniewierzeniem funduszy pokazuje, że po wielu latach przymykania oczu na działania antyliberalne i antyunijne Wspólnota postanowiła przynajmniej utrudnić dokonywanie tego z wykorzystaniem własnych pieniędzy. Nie jest przesądzone, czy zaprojektowany mechanizm będzie skuteczny ${ }^{45}$. Pewną wskazówką mogą być losy środków finansowych na inwestycje w tzw. strefach wolnych od LGBT w Polsce. Do mediów przedostały się głównie informacje o wstrzymaniu tzw. funduszy norweskich, ale można wskazać także ostrożność organów $\mathrm{UE}^{46}$.

$45 E U$ values are law, after all: Enforcing EU values through systemic infringement actions by the European Commission and the member states of the European Union, "Yearbook of European Law" 2020, vol. 39, s. 3-121; D. Ciolos, Rule-of-law deal: major step for Europe of values, EUobserver [online], 11 XI 2020 [dostęp: 22 VIII 2021]: <https://euobserver. com/opinion/150001>; R. Bellemy, S, Kroger, Countering democratic backsliding by EU member states: Constitutional pluralism and 'value' differentiated integration, "Swiss Political Science Review" 2021, vol. 27, no. 3, s. 1-18, DOI: 10.1111/spsr.12448.

46 EU funding withheld from six Polish towns over 'LGBT-free' zones, Euronews [online], 30 VII 2020 [dostęp: 24 VIII 2021]: <https://www.euronews.com/2020/07/29/ eu-funding-withheld-from-six-polish-towns-over-lgbtq-free-zones $>$; How the EU can stop Poland's 'LGBT-free zones', DW [online], 25 IX 2020 [dostęp: 22 VIII 2021]: <https://www.dw.com/en/how-the-eu-can-stop-polands-lgbt-freezones/a-55042896>; PE przyjąt rezolucję: Unia Europejska strefa wolności osób LGBTIQ. Komunikat Biura RPO, Rzecznik Praw Obywatelskich [online], 12 III 2021 [dostęp: 22 VIII 2021]: <https:/www.rpo.gov.pl/pl/content/ pe-rezolucja-unia-europejska-strefa-wolnosci-osob-lgbtiq-komunikat-biura-rpo $\rangle$. 
Dodatkowo kryzys związany z pandemią covid-19 umocnił tendencje do polityzacji projektu europejskiego. Uczestnictwo w nim i sama jego sensowność w obecnych warunkach nie są już elementami ponadpartyjnego konsensu oraz postrzeganej jako dobro wspólne racji stanu, ale przedmiotem intensywnego sporu politycznego i źródłem identyfikacji. Pierwszym krokiem ku temu było uformowanie się obozu eurosceptycznego przed wyborami do PE w 2009 r. Sztandar antyunijny okazał się atrakcyjnym punktem zbornym dla ruchów populistycznych i antysystemowych, które dzięki sprzeciwowi wobec reguł całej rzeczywistości politycznej - w tym w jej warstwie europejskiej - zdobyły istotną popularność. Na myśl przychodzi przede wszystkim wygrana Ligi i Ruchu 5 Gwiazd w wyborach parlamentarnych w 2018 r. we Włoszech, przejście Marine Le Pen do II tury wyborów prezydenckich we Francji w 2017 r. oraz wygrana Pis w wyborach w Polsce 2015 r. Z czasem zaczął się też kształtować spóźniony obóz proeuropejski, którego liderem chciał zostać Emmanuel Macron ${ }^{47}$, choć równie często jego twarzą była "mateczka” Merkel. Wspomniane wyżej dwie fundamentalne decyzje wskazują na wolę zebrania się pod sztandarem prointegracyjnym, który jest nie tylko symbolem, ale zawiera w sobie dwa współistniejące elementy: poziom i styl życia, czyli osiągnięcia socjalne i wartości.

Program Nowego Zielonego Ładu to narzędzie odzyskania inicjatywy przez wspomniany obóz. Tłumaczy to względną zgodę między państwami członkowskimi i Komisją w jego formułowaniu i promowaniu. Proeuropejskie rządy dostrzegły swój interes w promowaniu stabilizacji i odbudowie zaufania do projektu europejskiego. Europa ma stać się bardziej zielona, bardziej cyfrowa, bardziej przyjazna dzisiejszym i przyszłym obywatelom - aby tak się stało, niezbędne są działania wspólne na poziomie europejskim. Ten sposób legitymizowania projektu - poprzez podkreślanie kompetencji w realizacji celów ważnych społecznie, podzielanych przez osoby, które myślą o sobie, że są nowoczesne - wyraźnie różni się od wcześniejszego komunikatu o bezalternatywności integracji. Słuszna wydaje się zatem teza, że podtrzymanie i rozbudowa programu modernizacji

47 F. Bruno, Emmanuel Macron: a leader who speaks up for Europe, EUVisions [online], 5 II 2018 [dostęp: 22 VIII 2021]: 〈http://www.euvisions.eu/emmanuel-macron-leader-europe/ $>$; It's cool to be pro-EU with popular French President Emmanuel Macron, DW [online], 22 VI 2017 [dostęp: 22 VIII 2021]: 〈https://www.dw.com/en/its-cool-to-be-pro-eu-with-popular-french-president-emmanuel-macron/a-39376173 $\rangle$. 
sformułowanego przed wybuchem pandemii była możliwa przez dostrzeżenie synergiii interesów państw członkowskich - określanych przez prounijne rządy - i instytucji UE, przede wszystkim Komisji. Nieliczne sprzeciwiające się nowoczesności rządy (Polska i Węgry) zostały zmarginalizowane i właściwie napiętnowane, ale jednocześnie stworzono im warunki do pozostania w projekcie, ustępując w kwestii szczegółowych zapisów rozporządzenia o przestrzeganiu zasady praworządności oraz terminu i rodzaju zobowiązań do osiągnięcia neutralności emisyjnej. Ustępstwa te nie mają wielkiego znaczenia nie dlatego, że są nieistotne per se, ale dlatego, że wspólnota celów pozostałych aktorów czyni je nieistotnymi. Determinacja np. w osiąganiu zeroemisyjności wyróżnia (piętnuje) państwa pozostające $\mathrm{z}$ tyłu bez względu na to, czy zobowiązania podjęte w tym zakresie będą miały charakter prawny czy polityczny. Możliwość stopniowania surowości interpretacji wspomnianego rozporządzenia tworzy element nacisku i odróżniania "dobrych Europejczyków” od tych niepoprawnych, jadących „na gapę”.

Jeszcze ważniejszy jest fakt budowania narracji o przydatności UE jako źródła zasobów. Niemiecka zgoda na wspólne zadłużenie, które postulowano przecież jako instrument radzenia sobie z kryzysem strefy euro po $2008 \mathrm{r}^{48}$, to wynik kalkulacji - nadanie nowej dynamiki i legitymizacji projektowi integracyjnemu są istotniejsze od, zdawałoby się, nienegocjowanych niemieckich reguł oszczędności. Jak bardzo zręcznie ujął to Piotr Buras w 2019 r.: „Niemcy bronią status quo. Nie dlatego, że mają jakiś wielki plan, tylko raczej siłą bezwładu. Wszystkie poważne zmiany w Unii wymagałyby wymyślenia się przez Niemcy na nowo i wytłumaczenia tego wyborcom. Wymagałyby głębokich zmian w doktrynie ekonomicznej i w modelu gospodarczym, teraz nastawionym wyłącznie na eksport"49. Niemcy zmieniły zdanie, dostrzegając szansę na odbudowę zaufania do projektu, w którym grają pierwsze skrzypce. Odpowiedzialność za realizację

48 M. Mathijs, K. McNamara, The euro crisis' theory effect: Northern saints, southern sinners, and the demise of the Eurobond, "Journal of European Integration" 2015, vol. 37, issue 2, s. 229-245, DOI: 10.1080/07036337.2014.990137; German conservatives' eurobond awakening, Politico [online], 20 V 2020 [dostęp: 22 VIII 2021]: <https://www. politico.eu/article/germany-conservatives-eurobond-awakening/ $>$.

49 Czy niemiecka solidność niszczy Europę? Wywiad Waldemara Sroczyńskiego z Piotrem Burasem, Gazeta.pl [online], 16 XII 2019 [dostęp: 22 VIII 2021]: <https://next.gazeta. $\mathrm{pl} /$ next/7,151003,25517232,czy-niemiecka-solidnosc-niszczy-europe-buras-oni-nie-sa-w.html>. 
odbudowy jest podzielona między Komisję a państwa członkowskie, a kluczowym jej elementem jest modernizacja, tak aby każda sfera stawała się bardziej zielona, cyfrowa, otwarta i różnorodna. Jest to finalny krok na drodze repozycjonowania ekologii jako kwestii horyzontalnej i elementu stylu życia; niegdysiejszy luksus bogatych i fanaberia lewicującej młodzieży ostatecznie staje się jednym z kluczowych elementów europejskiego mainstreamu. Co więcej, Zielony Ład ma pochłaniać gros środków finansowych, a proekologiczność ma być zasadą całego instrumentu odbudowy. Istniejące jeszcze kilkanaście lat temu napięcie między wzrostem gospodarczym a troską o środowisko zostało przezwyciężone. Na razie na płaszczyźnie dokumentów i definiowania celów politycznych. Realizacja instrumentu NGE pokaże stopień przełożenia na rzeczywistość.

Synergia interesów państw członkowskich i Komisji umożliwiła „podkręcenie" agendy modernizacyjnej w warunkach pandemicznych. Nie musiało tak się stać, można łatwo było wyobrazić sobie zawieszenie określonych celów lub odłożenie ich na "lepsze czasy”. Fakt, że tak się nie stało, jest wyraźną przesłanką do następujących twierdzeń:

- Niemcy czują się realnie odpowiedzialne za podtrzymanie i sukces projektu integracyjnego, nawet jeśli wymaga to szczególnych, doktrynalno-ekonomicznych „ofiar”, przede wszystkim zgody na uwspólnotowienie długu;

- obóz postępowo-modernizacyjny jest niejednorodny, ale silny i zdolny do wygenerowania odpowiedzi na program eurosceptyczny;

- integracja posuwa się wtedy, gdy interesy instytucji i większości państw członkowskich są postrzegane jako zbieżne, a komisja "trafia” w popyt na rozwiązania zgłłaszany przez państwa członkowskie.

Powiązanie legitymizacji z modernizacją oraz wykorzystanie pandemicznego „okna możliwości” wykazania pożytków płynących z istnienia UE i jej aktywności to kluczowe elementy prointegracyjnego programu politycznego na najbliższy okres. Ochrona środowiska i Europa cyfrowa tworzą podstawowe płaszczyzny wskazanego wyżej powiązania poziomu europejskiego oraz jednostki. Tym samym znaczenie Zielonego Ładu znacząco wykracza poza realizację celów czysto prośrodowiskowych. Sukces w uczynieniu gospodarki bardziej zieloną przy zachowaniu poziomu życia to bilet do odbudowy zaufania do projektu europejskiego i przejęcia inicjatywy z rąk eurosceptyków. Ewentualna porażka to dalsze 
osłabienie nie tyle nawet autorytetu instytucji europejskich i przywódców politycznych - nawet tych "sprawdzonych w boju”, jak Angela Merkel co kluczowej opowieści o europejskim pokoju i dobrobycie osiągniętym dzięki i poprzez integrację.

Należy pamiętać, że za wzrostem wpływu działań podejmowanych na poziomie unijnym na życie obywateli nie poszła wiedza o mechanizmach funkcjonowania systemu unijnego - mamy zatem obywateli nieświadomych, podatnych na manipulację oraz bardzo złożony, hybrydowy system, którego funkcjonowanie bezskutecznie usiłujemy im wytłumaczyć. Propozycje zasilane nostalgią za przeszłą, jasno zdefiniowaną i homogeniczną wspólnotą polityczną są nie tylko o wiele prostsze do przyswojenia i łatwiejsze do zakomunikowania, ale mierzą się także z opowieścią, którą bardzo łatwo przedstawić jako intencjonalnie złożoną - narzędzie zaciemniania rzeczywistości przez kosmopolityczne elity. Tymczasem na mocy intersubiektywnej zgody wspólnota chce jednocześnie zachować suwerenność państw członkowskich, jedność rynku i sterowność w świecie pełnym turbulencji. Przywódcy europejscy opierają się pokusie rezygnacji z jednej z tych wartości, co rozwiązałoby przynajmniej część napięć. Skupienie na odbudowie gospodarczej za pomocą proekologicznej modernizacji oraz cyfryzacji pozwala zbudować przekaz skierowany do różnych grup społecznych. Fakt przekazywania środków finansowych jest atrakcyjny dla wyborców skupionych na sprawach lokalnych, wymiar dbania o planetę przemawia do młodych oraz rodziców. Nie mamy oczywiście do czynienia z przełamaniem głębokiej nieufności między elitami a „zwykłymi obywatelami", co było podstawowym paliwem dla ruchów populistycznych, zwykle także eurosceptycznych, ale działaniem wobec zagrożenia, które pokazuje to, co wspólne, bardziej niż retoryka tożsamościowa, kluczowa w mobilizowaniu swoich zwolenników.

Na koniec warto odnieść się do miejsca Polski w wyżej zarysowanym planie politycznym. Jego struktura nie przypisuje go nam apriorycznie, mimo najwyższego w UE uzależnienia od węgla. Warto pamiętać, że Niemcy również spalają ogromne ilości węgla brunatnego i po rezyǵnacji z energii atomowej też dokonywać muszą transformacji. Świadomość nieodwracalności określonych trendów przebiła się do obszaru zainteresowania polskiej klasy politycznej, w tym obecnie rządzących. Deklaracja premiera Mateusza Morawieckiego o popieraniu starań neutralności 
emisyjnej do $2050 \mathrm{r}$. jest tego świadectwem ${ }^{50}$, podobnie nowa umowa dla górnictwa ${ }^{51}$ i decyzja o wyburzeniu rozpoczętej budowy nowego bloku elektrowni w Ostrołęce ${ }^{52}$. Jednak bycie najmniej skłonnym do jak najbardziej opóźnionych zmian strukturalnych w zakresie energetyki nie jest najważniejszym problemem. Kluczowym elementem planu europejskiego mainstreamu, reprezentowanego przez instytucje i najważniejsze państwa członkowskie oraz część społeczeństwa obywatelskiego jest progresywna modernizacja, polegająca nie tylko na docenieniu kwestii ochrony klimatu i środowiska, ale także budowy otwartego, na innych i innowacje, społeczeństwa. Konserwatyzm i przywiązanie do rozwiązań typu „tak drzewiej bywało" i „tak ojcowie wierzyli”, które jest ważnym elementem strategii budowania poparcia przez prawicowy obóz rządzący, staje się poważną przeszkodą w pełnym wykorzystaniu możliwości oferowanych przez program modernizacyjny. Chęć zachowania tradycyjnych struktur społecznych i rozumienia określonych instytucji, sama w sobie będąca jak najbardziej dozwolonym elementem programu politycznego, tworzy poważne napięcie w realizacji tego, co jeden z ministrów określił kilka lat temu jako poglądy „wegan i cyklistów”. Niechęć do „sojowego latte” elit wielkomiejskich, które sprzeciwiają się programowi konserwatywnemu, stała się elementem tożsamości politycznej Pis i jego sojuszników. Postawienie na pierwszym miejscu zachowania i umocnienia jednolitego etnicznie i religijnie katolickiego narodu grozi marginalizacją w Europie. Nie stanie się to na mocy złośliwej decyzji innych, ale niewykorzystania szans z racji dania pierwszeństwa innym celom, które wymagają zamykania, a nie otwierania społeczeństwa. $\mathrm{W}$ połączeniu z antyunijną retoryką tworzy to niebezpieczeństwo trwałej peryferyzacji Polski (i szerzej subregionu). Poziom obecności frakcji pyłów

50 D. Rząsa, Będą wyższe cele redukcji emisji, ale bez wskazywania na konkretne kraje tak wygląda klimatyczny kompromis szczytu UE, 300Gospodarka [online], 11 XII 2020 [dostęp: 22 VIII 2021]: <https://3oogospodarka.pl/news/kolejne-porozumienie-na-szczycie-ue-ustalila-nowe-ambitniejsze-cele-redukcji-emisji $>$.

51 Ruszyła rozbiórka Ostrołęki C. Niedoszła elektrownia kosztowała miliard złotych, Business Insider [online], 10 III 2021 [dostęp: 22 VIII 2021]: <https://businessinsider.com.pl/firmy/strategie/ruszyla-rozbiorka-konstrukcji-elektrowni-w-ostrolece/ bpodhmz>.

52 Umowa społeczna dla górnictwa podpisana, Ministerstwo Aktywów Państwowych [online], 28 V 2021 [dostęp: 22 VIII 2021]: <https://www.gov.pl/web/ aktywa-panstwowe/umowa-spoleczna-dla-gornictwa-podpisana $>$. 
w miastach ${ }^{53}$ i zależność od węgla będą tego zewnętrznymi przejawami. Jednak peryferyzacja oznacza przede wszystkim odcięcie od centrum podejmowania decyzji, co nie dokona się spektakularnie i jednorazowo (chyba że taki będzie wybór rządzących Polską), lecz poprzez umocnienie już istniejących trendów. Trwałe "niespodziewanie się niczego konstruktywnego" po polskim rządzie będzie owocować marginalizacją poprzez pozostawienie w spokoju. Niebezpieczeństwo to jest realne i musi być brane od uwagę w kalkulacjach politycznych ${ }^{54}$. Konsekwencji decyzji podejmowanych dziś, w dobie przynajmniej taktycznego konfliktu z UE, nie znamy, lecz doświadczenie projektu integracyjnego uczy, że kluczowe dla przyszłości skrzyżowanie i dokonany wybór ścieżki często jawią się jako niepierwszoplanowe. Peryferyzacja może "przytrafić się" jako konsekwencja działania stawiającego na pierwszym miejscu budowanie poparcia wewnątrz państwa. Byłoby to działanie przeciwko interesowi narodowemu podjęte mimochodem, co czyni jego konsekwencje tym bardziej nieznośnymi.

\section{Bibliografia}

Bajric E., Could the "corona crisis" be a chance for a better future?, EyesOnEurope [online], 5 VIII 2020 [dostęp: 22 VIII 2021]: <https://www.eyes-on-europe.eu/ could-the-corona-crisis-be-a-chance-for-a-better-future/ $>$.

Bellemy R., Kroger S., Countering democratic backsliding by EU member states: Constitutional pluralism and 'value' differentiated integration, "Swiss Political Science Review" 2021, vol. 27, no. 3, s. 1-18, DOI: 10.1111/spsr.12448.

Bénassy-Quéré A., Weder di Mauro B., European pandemic recovery: an opportunity to reboot, "Intereconomics" 2020, vol. 55, no. 4, pp. 205-209, DOI: $10.1007 /$ s10272-020-0903-3.

Bez państwa dobrobytu i strategii rozwoju Europa nie będzie dobrym miejscem do życia, Onet Wiadomości [online], 14 III 2021 [dostęp: 22 VIII 2021]: $<$ https://wiadomosci.onet.pl/opinie/bez-panstwa-dobrobytu-i-strategii-rozwojueuropa-nie-bedzie-dobrym-miejscem-do-zycia/m39pcyw $\rangle$.

53 Polska jest najmocniej zapylonym krajem w Unii Europejskiej, „Rzeczpospolita” [online], 24 XII 2020 [dostęp: 22 VIII 2021]: <https://www.rp.pl/Smog/311239924Polska-jest-najmocniej-zapylonym-krajem-w-Unii-Europejskiej.html .

54 Is Warsaw facing de facto Polexit?, DW [online], 7 XII 2020 [dostęp: 22 VIII 2021]: $\langle$ https://www.dw.com/en/is-warsaw-facing-de-facto-polexit/a-55836884>; C. Bradley, $E U$ told 'Polexit process may have already started' as bloc warned of Brexit repeat, Express [online], 5 V 2021 [dostęp: 22 VIII 2021]: <https://www.express.co.uk/news/ world/1380167/eu-news-polexit-poland-brexit-repeat-hungary-spt $\rangle$. 
Borkowski P., Unia Europejska-próba przedolimpijska, „Rocznik Strategiczny” 2018/2019, s. 187-208.

Bradley C., EU told 'Polexit process may have already started' as bloc warned of Brexit repeat, Express [online], 5 V 2021 [dostęp: 22 VIII 2021]: 〈https://www.express. co.uk/news/world/1380167/eu-news-polexit-poland-brexit-repeat-hungary-spt $\rangle$.

Bruno F., Emmanuel Macron: a leader who speaks up for Europe, EUVisions [online], 5 II 2018 [dostęp: 22 VIII 2021]: <http://www.euvisions.eu/emmanuelmacron-leader-europe/ $>$.

Carrieri L., The impact of European integration on West European politics, Palgrave Macmillan, London 2020.

Chemicals strategy for sustainability. Towards a toxic-free environment, Communication from the Commission to the European Parliament, the Council, the European Economic and Social Committee and the Committee of the Regions, COM (2020) 667 final, 14 X 2020.

Cianciara A., Europejska Polityka Sąsiedztwa w perspektywie konstruktywizmu, Instytut Studiów Politycznych PAN, Warszawa 2017.

Ciolos D., Rule-of-law deal: major step for Europe of values, EUobserver [online], $11 \mathrm{XI}$ 2020 [dostęp: 22 VIII 2021]: 〈https://euobserver.com/opinion/150001〉.

Colli F., The end of "bussines as usual"? COVID-19 and the European Green Deal, Egmont Institute, Brussels 2020 (Policy Brief No 60).

Czech PM urges EU to ditch Green Deal amid virus, Euractiv [online], 17 III 2020 [dostęp: 22 VIII 2021]: <https://www.euractiv.com/section/energy-environment/ news/czech-pm-urges-eu-to-ditch-green-deal-amid-virus/>.

Czy niemiecka solidność niszczy Europę? Wywiad Waldemara Sroczyńskiego z Piotrem Burasem, Gazeta.pl [online], 16 XII 2019 [dostęp: 22 VIII 2021]: <https://next. gazeta.pl/next/7,151003,25517232,czy-niemiecka-solidnosc-niszczy-europe-burasoni-nie-sa-w.html>.

Delivering a circular economy within the planet's boundaries. An analysis of the new EU Circular Economy Action Plan, Stockholm Environment Institute 2020.

Doyle A., Four more EU nations back a green post-coronavirus recovery, Climate Home News [online], 20 IV 2020 [dostęp: 22 VIII 2021]: <https://www.climatechangenews. com/2020/o4/20/four-eu-nations-back-green-post-coronavirus-recovery/ $>$.

Elkerbout M., Egenhofer C., Ferrer J. N., Cătuţi M., Kustova I., Rizos V., European Green Deal after corona: Implications for EU climate policy, CEPS Policy Insight [online], 31 III 2020, s. 2: <https://www.ceps.eu/wp-content/uploads/2020/03/ PI2020-06_European-Green-Deal-after-Corona.pdf $>$ [dostęp: 22 VIII 2021].

Elliott L., The coronavirus crisis has brought the EU's failings into sharp relief, The Guardian News [online], 29 III 2020, [dostęp: 22 VIII 2021]: <https://www. theguardian.com/business/2020/mar/29/the-coronavirus-crisis-has-broughtthe-eus-failings-into-sharp-relief $>$.

EU funding withheld from six Polish towns over 'LGBT-free' zones, Euronews [online], 30 VII 2020 [dostęp: 24 VIII 2021]: 〈https://www.euronews.com/2020/o7/29/ eu-funding-withheld-from-six-polish-towns-over-lgbtq-free-zones $\rangle$. 
The E.U.'s ominous new name for a top migration job? Vice president for 'Protecting our European Way of Life', "The Washington Post" [online], 10 VIII 2019 [dostęp: 22 VIII 2021]: <https://www.washingtonpost.com/world/2019/og/10/eus-ominous-new-name-top-migration-job-vice-president-protecting-our-european-way-life/>.

$E U$ values are law, after all: Enforcing EU values through systemic infringement actions by the European Commission and the member states of the European Union, "Yearbook of European Law" 2020, vol. 39, s. 3-121.

Europa i USA nie wyǵrają wyściğu o przywództwo z Chinami zwiększając zaangaażowanie państwa w gospodarkę, Onet Wiadomości [online], 12 III 2021 [dostęp: 22 VIII 2021]: <https://wiadomosci.onet.pl/opinie/europa-i-usa-nie-wygrajawyscigu-o-przywodztwo-z-chinami-zwiekszajac-zaangazowanie/p77p881 .

European Green Deal must be central to a resilient recovery after Covid-19, Climate Home News [online], 9 IV 2020 [dostęp: 22 VIII 2021]: <https://www. climatechangenews.com/2020/04/o9/european-green-deal-must-central-resilientrecovery-covid-19/>.

Europejska agenda cyfrowa, Komunikat Komisji do Parlamentu Europejskiego, Rady, Europejskiego Komitetu Ekonomiczno-Społecznego i Komitetu Regionów, $\operatorname{com}(2010) 0245$ final.

Europejski Zielony Lad, Komunikat Komisji do Parlamentu Europejskiego, Rady Europejskiej, Rady, Komitetu Ekonomiczno-Społecznego i Komitetu Regionów, $\operatorname{COM}(2019) 640$ final, Komisja Europejska, Bruksela 2019, s. 2: $<$ https://eur-lex.europa.eu/resource.html?uri=cellar:b828d165-1c22-11ea-8c1fo1aa75ed71a1.0016.02/DOC_1\&format=PDF> [dostęp: 22 II 2021].

The geopolitics of the European Green Deal, ECFR Policy Brief [online], 3 III 2021 [dostęp: 22 VIII 2021]: <https://ecfreu/publication/the-geopolitics-of-theeuropean-green-deal/>.

German conservatives' eurobond awakening, Politico [online], 20 V 2020 [dostęp: 22 VIII 2021]: <https://www.politico.eu/article/germany-conservatives-eurobondawakening/>.

Hartleb F., Here to stay: anti-establishment parties in Europe, "European View" 2015, vol. 14, no. 4, s. 39-49.

Hofhuis P., The European Commission on the brink of a green recovery. Will it be able to deliver?, Netherlands Institute of International Relations, Clingendale 2020 (Policy Brief).

How Europe failed the coronavirus test, Politico.eu [online], 7 IV 2020 [dostęp: 22 VIII 2021]: 〈https://www.politico.eu/article/coronavirus-europe-failed-the-test/ $>$.

How the EU can stop Poland's 'LGBT-free zones', DW [online], 25 IX 2020 [dostęp: 22 VIII 2021]: $\langle$ https://www.dw.com/en/how-the-eu-can-stop-polands-lgbt-freezones/a-55042896>.

How the EU's Green Deal survived the coronavirus pandemic, Politico.eu [online], 17 XII 2020 [dostęp: 22 VIII 2021]: 〈https://www.politico.eu/article/how-euclimate-change-promises-survived-the-coronavirus-plague/ $>$. 
Is the EU failing on crisis management?, euro topics [online], 18 III 2020 [dostęp: 22 VIII 2021]: $\langle$ https://www.eurotopics.net/en/237142/is-the-eu-failing-on-crisismanagement $>$.

Is Warsaw facing de facto Polexit?, DW [online], 7 XII 2020 [dostęp: 22 VIII 2021]: $\langle$ https://www.dw.com/en/is-warsaw-facing-de-facto-polexit/a-55836884 .

It's cool to be pro-EU with popular French President Emmanuel Macron, DW [online], 22 VI 2017 [dostęp: 22 VIII 2021]: <https://www.dw.com/en/its-cool-to-be-pro-eu-with-popular-french-president-emmanuel-macron/a-39376173〉.

Kowalski: Koronawirus każe wyłączyć Polskę z ETS i zapomnieć o Europejskim Zielonym Ładzie, Biznes Alert [online], 18 III 2020 [dostęp: 22 VIII 2021]: <https://biznesalert. $\mathrm{pl} /$ kowalski-wylaczyc-polske-z-ets-europejski-zielony-lad-energetyka-klimat/>.

Lamy P., Greener after: A green recovery stimulus for Europe, Jacques Delors Institute, Paris 2020.

Macron, Merkel call for swift agreement on EU Covid-19 recovery fund, rfi [online], $29 \mathrm{VI}$ 2020 [dostęp: 22 VIII 2021]: 〈https://www.rfi.fr/en/europe/20200629-macron-and-merkel-meet-ahead-of-decisive-german-presidency-of-eu $\rangle$.

Mathijs M., McNamara K., The Euro Crisis' Theory Effect: Northern Saints, Southern Sinners, and the Demise of the Eurobond, "Journal of European Integration" 2015, vol. 37, issue 2, s. 229-245, DOI: 10.1080/07036337.2014.990137.

Mérand F., Bricolage: A sociological approach to the making of CSDP, [w:] Explaining the EU's Common Security and Defense Policy, eds X. Kurowska, F. Breuger, Palgrave Macmillan, London 2012 (Palgrave Studies in European Union Politics).

Merkel and Macron show unity ahead of all-important EU summit, EUraktiv [online], 30 VI 2020 [dostęp: 22 VIII 2021]: 〈https://www.euractiv.com/section/future-eu/ news/merkel-and-macron-show-unity-ahead-of-all-important-eu-summit/ $>$.

Mój program dla Europy: wytyczne polityczne na następna kadencje Komisji Europejskiej (2019-2024), Unia Europejska 2019, DOI: 10.2775/612705.

Movarelli M., EU democracy in the times of coronavirus, "European View" 2020, vol. 19, issue 2, s. 180-187, DOI: 10.1177/1781685820967770.

New EU Commission delayed for at least a month, EUractiv [online], 17 X 2019 [dostęp: 22 VIII 2021]: $\langle$ https://www.euractiv.com/section/eu-elections-2019/news/new-eucommission-delayed-for-at-least-a-month/ $>$.

PE przyjął rezolucję: Unia Europejska strefa wolności osób LGBTIQ. Komunikat Biura RPO, Rzecznik Praw Obywatelskich [online], 12 III 2021 [dostęp: 22 VIII 2O21]: $<$ https://www.rpo.gov.pl/pl/content/pe-rezolucja-unia-europejska-strefa-wolnosci-osob-lgbtiq-komunikat-biura-rpo $\rangle$.

Polska jest najmocniej zapylonym krajem w Unii Europejskiej, „Rzeczpospolita” [online], 24 XII 2020 [dostęp: 22 VIII 2021]: <https://www.rp.pl/Smog/311239924-Polskajest-najmocniej-zapylonym-krajem-w-Unii-Europejskiej.html $>$.

Polska w Zielonym Ładzie - korzyści, możliwości i ocena SWOT, Kancelaria Senatu RP, Warszawa 2020 (Opinie i Ekspertyzy OE, 307).

Regierungserklärung von Bundeskanzlerin Merkel in Berlin vor dem Deutschen Bundestag (Protokoll des Deutschen Bundestages), Bundeskanzler [online], 
18 VII 2020 [dostęp: 22 VIII 2021]: <https://www.bundeskanzlerin.de/bkin-de/ aktuelles/regierungserklaerung-von-bundeskanzlerin-merkel-1762594 $\rangle$.

Ruszyła rozbiórka Ostrołęki C. Niedoszła elektrownia kosztowała miliard złotych, Business Insider [online], 10 III 2021 [dostęp: 22 VIII 2021]: 〈https://businessinsider. com.pl/firmy/strategie/ruszyla-rozbiorka-konstrukcji-elektrowni-w-ostrolece/ bpodhmz〉.

Rząsa D., Będą wyższe cele redukcji emisji, ale bez wskazywania na konkretne kraje tak wygiląda klimatyczny kompromis szczytu UE, 300Gospodarka [online], 11 XII 2020 [dostęp: 22 VIII 2021]: <https://30ogospodarka.pl/news/kolejne-porozumienie-na-szczycie-ue-ustalila-nowe-ambitniejsze-cele-redukcji-emisji $>$.

Salvati E., Vercesi M., Anti-system Eurosceptic parties: Where and why they succeded, EUVisions [online], 4 IX 2017 [dostęp: 22 VIII 2021]: <http://www.euvisions.eu/ archive/eurosceptic-parties-succeed/>.

Shaelou S. L., Why the coronavirus crisis is still a moment of opportunity for the European Union, The Conversation [online], 12 VI 2020 [dostęp: 22 VIII 2021]: $<$ https://theconversation.com/why-the-coronavirus-crisis-is-still-a-moment-of-opportunity-for-the-european-union-136877>.

Storm S., The EU's Green Deal: Bismarck's 'what is possible' versus Thunberg's 'what is imperative', Institute for New Economic Thinking, March 2020 (Working Paper No 117).

Surdykowska B., Owczarek D., Posted workers regulations as a cohesion test in the enlarged European Union: divergent interests of trade unions, employers' organisations and governments, Friedrich-Ebert-Stiftung, Bratislavia 2018.

The von der Leyen Commission: Lofty ambitions, odd job titles, Politico.eu [online], 10 IX 2019 [dostęp: 22 VIII 2021]: <https://www.politico.eu/article/ von-der-leyen-sets-priorities-with-new-commission-lineup/ $>$.

Umowa społeczna dla górnictwa podpisana, Ministerstwo Aktywów Państwowych [online], 28 V 2021 [dostęp: 22 VIII 2021]: <https://www.gov.pl/web/aktywapanstwowe/umowa-spoleczna-dla-gornictwa-podpisana $\rangle$.

What constitutes European green recovery?, Institute for European Environmental Policy [online], 28 VII 2020 [dostęp: 22 VIII 2021]: <https://ieep.eu/publications/ what-constitutes-a-european-green-recovery $\rangle$.

Zerka P., In sickness and in health: European cooperation during the coronavirus crisis, ECFR Policy Brief [online], 8 VI 2020 [dostęp: 22 VIII 2021]: <https://ecfreu/ publication/in_sickness_and_in_health_european_cooperation_during_coronavirus_crisis/>. 